特別発言 放射性同位元素の内科学的応用

隐床㭘查刃の放射能测定器について

大陇医科火学做射線医学教窒

狝木弘，燤

\title{
CLINICAL USES OF RADIOISITOPES IN ROUTINE EXAMINATION : SOME EXPERIMENTAL STUDIES ON CIRCUITS OF THE INSTRUMENTS
}

Hiroaki AKagi

Department of Radiology, Osaka Medical School

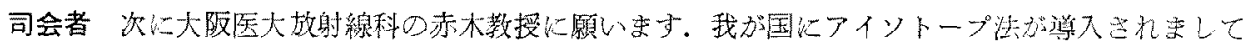

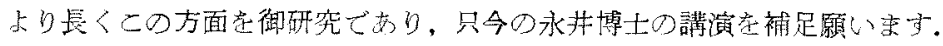

放射性同位元素の臨床検查面に於ける有用性は すでに充分認められているが，市販の放射能測定 器は物理学的寒駼を目的として発详した為に沉用 として設計され，従つて回路は相当複嵙で文高価 である，その為に臨床的検查に使用するには却つ て不便点点見出す場合加ある。従つて技街員が 使用し易々かつ臨床检查の目的に沿つた測定器の 必要を認めたので, scintillation counter, gasflowcounter, scaler, rate-meter scintiscanner等 作し，数年に亘り耐久力検楂を行つた。

その結果臨床的検查用の放射能湘定器としては 基礎的には次のような考えを得な。

1）使用者は挍術者が主で徙つて測定器に対す る知識は少ない場合が頻々である。一測定器は一 種の椮查にのみ固定使用する。その為に測定器の 特性は，その検查の最少限の必要性を充た方程度 に回路を簡熬化及は適合さす。

2) 前回八゚ネ儿面の調筋部分を最少限とし，愦 動作をさける。

3）測定室の空調の関係から测定器の発熱は诙 少限度とする，従つて半導体を主に使用す。

4)測定窒は空調特に给房は必要でニれで夏 の測定器の故障を著しく減少出来る（以下細目は
略する)。

最近試作した 2 channel rate-meter $と$ scintiscannerを報告する。

\section{2 channel rate-méter}

䛻環器機能検查とdouble tracer孝目的として, それぞれ 2 組の増䒇器, 波高分析器, 計数率計, 高压電源 3 インチ×2 インチ $\mathrm{NaI}(\mathrm{Tl})$ 結晶等より なり, 結框は 2 channel tape recorder $\varepsilon 4$ pen recorderk記錄再生される。附属品住記憶管oscilloscope と小型のanalog計算器が附属する。

特長は $1 / 10 に$ scale down $て$ てtape recorderに 入る為に普通のtape recorderが用いられる点と， 㭙定数さ0.1〜80秒間に10組取りっこれとlow pass filter䘮組み合す事により時間的当れを鶖視出来 る. 3 インチのNaI結晶に2 インチphotomultiplierを用いた為に鉛のshieldの效果が著しいの と， $\gamma$ 線の域值が直誌出来る点である。

\section{II. scintiseanner}

Scintiscannerのback groundの 除去方港は種々 有るが，pulse間の時間により pulseを制御する万 法を用いた。 pulse間の時間が一定時間より短い 場合のみ記錄し，更にこの回路に簡単な同時計数 回路を加光，等濃度(等計数)曲線を描加した。即 


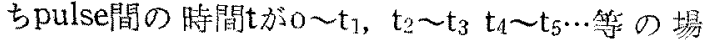
合にのみ記録する方法者用いた。

結果は従来のscintigramに比し酮哭の境界線

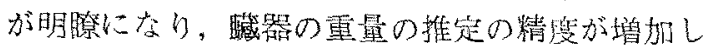
た，及等婊度曲線を描かす事により，臟器の異労
の発見が容易となり，又この等濃度曲線に適当に 色附话する專により color scintigramが従来より

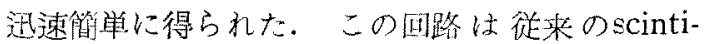

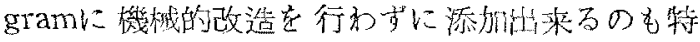
展である。

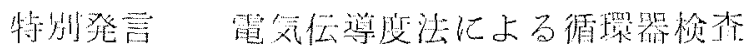

\title{
神戸医科大学第一内科 \\ 友松達弥, 種本基一郎 \\ CIRCULATORY FUNCTION TEST WITH ELECTRIC CONDUCTIVITY METHOD
}

Tatsuya Tomomatsu and Kiichiro Tanemoto

Kobe Medical College, Internal Medicine, Division I

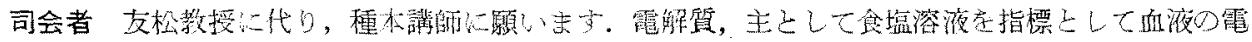

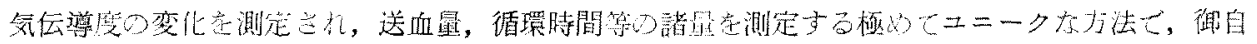

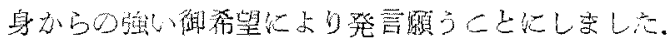

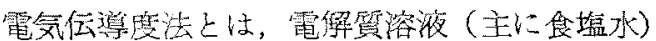
を指標として血液の電気伝湆度の変化ょり，血流 量を測定主る一種の指標稀稂法である。即ち，末 梢静脈に一定量の電解質溶液を注入して，末梢 勳脈に膤入した 2 電極上り，血液の電気伝導度の 変化抵抗の変化としてwheatstone bridge $の-$ つの腕に導き，そのbalanceの变化增幅してgal-

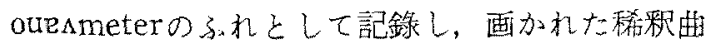
線よりStewart-Hamiltonの原理より心拍出量を

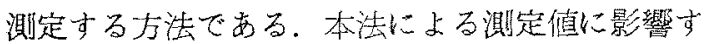
万各種要因については，既に検討を加え発表した (呼吸と循環 6 ：613，1958). 以後，本法によつて 下記の如き多方面の測定を行つてきな。

\section{（1）心拍出量の測定}

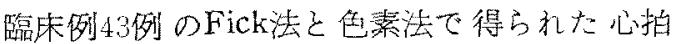
出量を比較すると，相関係数は+0.920であり，又 本法と色罻法及び心放射図法によつて得られた心 拍出量を比較すると, 相関係数は+0.965，+0.967
でよく一致した，次に本法によつて，動物実験 及び臨床例で，急性肺水腫時の左右心拍出量を測 定したが，発作時に右心拍出量が左心拍出量より 増加することをあきらかにした（呼吸と循環6： 933, 1958).

(2) 䛻環時間の測定

注大部位より電極までの循環洔間は，得られた 電気伝導度曲線内の面積を 2 分する平均通過特間 を計测することによつて，客観的に求めることが 出来る。なかんずく肺動脈上り腕動脈までの時間 を測定すれ洁，Ebert-Bordenのいわゆる肺循環 時間が得られ，更にそれに1秒心指出量を乘ずる ことによつている沙る肺血渡量が算出できる。

（3）靜服還流及びその体分布の測定 本法によつて分岐の集合よりなる大靜脈系で， 血流量定测定出来ることを模型実験で確かめ, 更 に方法猃上の諸問題を検討した(日循誌24：1297, 